\title{
Upaya Penghematan Air Bersih di Gedung Perkantoran \\ Studi Kasus : Penghematan Air di Gedung Kantor BPPT
}

\author{
Water Saving Efforts in Offices Building \\ Case Study : Water Saving in BPPT Office Building
}

\author{
SATMOKO YUDO \\ Pusat Teknologi Lingkungan, Badan Pengkajian dan Penerapan Teknologi \\ Gedung Geostech 820 Lt.2, Kawasan Puspiptek, Tangerang Selatan, Banten 15314 \\ satmoko.yudo@bppt.go.id
}

\begin{abstract}
The rapid growth of industrial and office has resulted in increasing demand and water use every year. The government is also working hard to reduce water consumption in the buildings and government offices, one of them by issuing Presidential Instruction (INPRES) No. 13 of 2011. Presidential instruction was published to provide a role model of the government apparatus to the community and efforts to change the extravagant behavior and away from the principle of efficiency in water consumption. The purpose of writing this paper is to identify the efforts that must be done in implementing water savings activities in office buildings. The Agency for Assessment and Application of Technology (BPPT) as a Non-Ministerial Government Institution has tried to implement that Inpres by making several efforts to save water. The most important factor of the effort is the commitment of top management to fully support the movement of water savings. Through this movement BPPT has significantly decreased water use (38.13\%) and has been recognized as an energy and water efficient building in the National Energy Efficiency Award organized by the Ministry of Energy and Mineral Resources.
\end{abstract}

Keywords : office buildings, water consumption, water saving efforts

\begin{abstract}
ABSTRAK
Pertumbuhan jumlah industri dan perkantoran yang pesat saat ini mengakibatkan kebutuhan dan pemakaian air yang terus meningkat setiap tahunnya. Pemerintah pun berupaya sekuat tenaga untuk mengurangi konsumsi air di lingkungan gedung dan perkantoran pemerintahan, salah satunya dengan mengeluarkan Instruksi Presiden (Inpres) Nomor 13 Tahun 2011. Instruksi presiden itu diterbitkan untuk memberikan panutan dari aparatur pemerintahan kepada masyarakat dan upaya mengubah perilaku boros dan jauh dari prinsip efisiensi pada pemakaian energi dan air. Tujuan dari penulisan paper ini adalah melakukan identifikasi upaya-upaya yang harus dilakukan dalam melaksanakan kegiatan penghematan air di gedung perkantoran. Badan Pengkajian dan Penerapan Teknologi (BPPT) sebagai Lembaga Pemerintah Non Kementerian telah berusaha melaksanakan Inpres tersebut dengan melakukan beberapa upaya untuk menghemat air. Faktor yang paling penting dari upaya tersebut adalah komitmen dari top manajemen untuk mendukung secara penuh pada gerakan penghematan air. Melalui gerakan ini, BPPT telah melakukan penurunan pemakaian air $(38,13 \%)$ yang signifikan dan telah memperoleh pengakuan sebagai gedung yang hemat energi dan air dalam lomba Penghargaan Efisensi Energi Nasional yang diselenggarakan oleh Kementerian Energi dan Sumber Daya Mineral.
\end{abstract}

Kata kunci : gedung perkantoran, pemakaian air, upaya penghematan air

\section{PENDAHULUAN}

\subsection{Latar Belakang}

Air bersih merupakan kebutuhan dasar manusia yang berdampak langsung kepada kesejahteraan fisik, sosial dan ekonomi masyarakat ${ }^{(1)}$. Sungai yang mengalir di kota besar khususnya di wilayah Jakarta yang menjadi sumber air bersih sudah tercemar mulai dari air limbah domestik hingga limbah beracun dari industri. Pemakaian air tanah yang terus menerus dengan jumlah yang besar mengakibatkan menurunnya cadangan air tanah. 
Selain itu kualitas air tanah semakin menurun akibat instrusi air laut dan pencemaran buangan air limbah rumah tangga. Salah satu upaya untuk menghindari kelangkaan air bersih adalah melakukan penghematan penggunaan air bersih dan melakukan upaya-upaya konservasi sumber daya air. Sebagai upaya untuk penghematan air, Pemerintah telah menerbitkan beberapa peraturan perundang undangan antara lain`: Peraturan Pemerintah Nomor 42 Tahun 2008 tentang Pengelolaan Sumber Daya Air (2), Instruksi Presiden Republik Indonesia Nomor 13 Tahun 2011 Tentang Penghematan Energi dan Air ${ }^{(3)}$, Peraturan Menteri Energi dan Sumber Daya Mineral Republik Indonesia Nomor 15 Tahun 2012 Tentang Penghematan Penggunaan Air Tanah ${ }^{(4)}$, dan Peraturan Menteri Pekerjaan Umum Republik Indonesia Nomor 12/PRT/M/2013 Tahun 2013 Tentang Penghematan Penggunaan Air yang berasal dari Penyelenggara Sistem Penyediaan Air Minum di Lingkungan Instansi Pemerintah, Pemerintah Daerah, Badan Usaha Milik Negara dan Badan Usaha Milik Daerah(5). Mengacu pada peraturan perundang-undangan ini, setiap gedung perkantoran khususnya milik pemerintah mempunyai kewajiban untuk melakukan penghematan air sebesar 10\% (sepuluh persen) dari pemakaian air rata-rata 6 (enam) bulan sebelumnya. Dalam rangka usaha untuk mendukung kegiatan penghematan air ini, Badan Pengkajian dan Penerapan Teknologi (BPPT) berupaya melakukan kajian terhadap semua kegiatan pemakaian air melalui upaya penghematan pemakaian air bersih, melakukan konservasi air dan menjaga ketersediaan sumberdaya air.

BPPT terletak di Jl. M.H. Thamrin No.8, Kelurahan Kebon Sirih, Kecamatan Menteng, Kotamadya Jakarta Pusat. BPPT mempunyai dua buah gedung yaitu Gedung I yang memiliki 21 lantai dibangun tahun 1974-1977 dan gedung II memiliki 24 lantai. Luas lahan perkantoran sekitar 2,5 ha dengan luas lantai bangunan kurang lebih dari $50.000 \mathrm{~m}^{2}$.

Sumber utama air bersih berasal dari air PAM Palyja Jakarta dan ditampung dalam ground tank dengan kapasitas volume $300 \mathrm{~m}^{3}$ yang didistribusikan ke beberapa tangki penyimpanan air. Untuk mensubstitusi kebutuhan air, juga digunakan air hasil olahan (daur ulang) air limbah domestik dengan kapasitas $10 \mathrm{~m}^{3}$.

\subsection{Tujuan}

Tujuan kegiatan ini adalah melakukan identifikasi upaya-upaya penghematan air bersih di gedung BPPT dengan sasaran terciptanya kondisi kepedulian terhadap pelestarian sumber daya air.

\section{BAHAN DAN METODOLOGI}

Obyek penelitian ini adalah Gedung BPPT meliputi kegiatan:

(1) Pengumpulan data sekunder dan primer gedung BPPT.

(2) Survei \& observasi lapangan di gedung BPPT.

(3) Mengetahui kondisi sistem distribusi air, peralatan pemakaian dan data pendukung.

(4) Sampling dan analisa kualitas air, yaitu air PAM, air daur ulang dan air buangan AC di lingkungan perkantoran BPPT.

Metodologi yang digunakan dalam kegiatan ini adalah :

(1) Studi Pustaka,

(2) Interview dan observasi,

(3) Analisa upaya-upaya efisiensi hemat air,

(4) Perhitungan efisiensi penghematan air sebelum dan setelah dilakukan upayaupaya.

\section{HASIL DAN PEMBAHASAN}

\subsection{Upaya-upaya Penghematan Air yang Dilakukan}

Beberapa upaya yang telah dilakukan BPPT untuk dapat menghemat air antara lain adalah:

\section{a. Komitmen Top Manajemen}

Menurut Kamus Besar Bahasa Indonesia, yang dimaksud dengan komitmen adalah membuat perjanjian (keterikatan) untuk melakukan sesuatu atau kontrak(6). Top manajemen perkantoran harus mempuyai komitmen yang mendukung secara penuh gerakan penghematan energi dan air. Tanpa komitmen tersebut implementasi gerakan hemat energi \& air tidak akan sukses ${ }^{(7)}$.

Kepala BPPT pada tanggal 16 Desember 2011 telah menandatangani komitmen untuk mendukung kebijakan program pemerintah di Bidang Penghematan Energi dan Air serta Gerakan Nasional Indonesia Bersih melalui upaya:

(1) Menjadikan kantor BPPT sebagai kantor yang bersih, hemat energi dan air;

(2) Mengembangkan budaya BPPT ke arah budaya bersih, hemat energi dan air;

(3) Melaksanakan inovasi teknologi untuk mendukung Gerakan Nasional Indonesia Besih, Hemat Energi dan Air.

\section{b. Pembetukan Tim Gugus Tugas}

Sebagai pelaksanakaan Instruksi Presiden RI Nomor 13 Tahun 2011, BPPT pada tanggal 16 Desember 2011 telah melaksanakan Launching Penghematan Energi dan Air dan membentuk tim gugus tugas penghematan 
energi dan air baik pada tingkat pusat maupun pada tingkat satuan kerja (Balai Besar/Balai). Tugas tim adalah:

(1) Melakukan koordinasi kegiatan-kegiatan penghematan energi dan air;

(2) Memantau segi penghematan energi dan air di lingkungan BPPT;

(3) Melakukan penilaian ruangan kerja dan lingkungan sekitar gedung dari segi efisiensi air di 45 unit kerja dan gedung satker dan non-satker di seluruh unit kerja BPPT baik pusat maupun daerah;

(4) Melakukan kajian dan evaluasi penghematan energi dan air.

\section{c. Audit Pemakaian Air}

Audit adalah pengumpulan dan evaluasi bukti tentang informasi untuk menentukan dan melaporkan derajat kesesuaian antara informasi itu dan kriteria yang telah ditetapkan. Audit harus dilakukan oleh orang yang kompeten dan independen ${ }^{(8)}$. Audit ini dimaksudkan untuk melakukan evaluasi terhadap semua kegiatan penggunaan air ditinjau dari sisi penghematan, pengawasan dan cara menggunakan sumber daya secara efisien. Inventarisasi data akan dilakukan dengan mengumpulkan data kondisi, pemakaian air untuk kebutuhan gedung dan pegawai serta kondisi keran, kamar mandi, toilet dan lainnya. Berdasarkan data-data yang terkumpul akan dilakukan pengolahan, analisa, dan evaluasi serta rekomendasi pemakaian air di gedung BPPT.

Hasil audit terhadap pemakaian air diperoleh beberapa rekomendasi antara lain(9) :

(1) Pemasangan meter air di beberapa titik yang berpotensi pemakaian airnya tinggi (kantin, dapur lantai 3, cuci kendaraan operasional dan bus karyawan).

(2) Perbaikan dan penggantian meter air yang rusak.

(3) Penggantian keran air manual menjadi keran tekan/autostop atau keran sensor.

(4) Perlu standar waktu bukaan keran autostop sehingga lebih menghemat.

(5) Perlu pengecekan secara berkala kondisi keran, urinoir, shower, toilet sehingga apabila ada kerusakan, kebocoran cepat diperbaiki.

(6) Perlu membangun unit pemanenan air hujan untuk mengurangi konsumsi pemakaian air bersih dari PAM.

(7) Perlu perbaikan sumur resapan air buangan AC.

(8) Perlu mengurangi pemakaian selang dan menambahkan sprinkler untuk menyiram tanaman.

\section{d. Sosialisasi}

Sosialisasi penghematan air yang merupakan bagian dari sosialisasi pennghematan energi dan air sebagai pelaksanaan Inpres RI Nomor 13 Tahun 2011 telah dilaksanakan BPPT kepada seluruh pegawai di unit yang ada dilingkungan BPPT termasuk pegawai outsoursing (satpam, cleaning service, office boy) untuk menjelaskan mengenai Manajemen Pengelolaan dan Penghematan Air di Perkantoran. Disamping sosialisasi, untuk meningkatkan kesadaran terhadap penghematan air juga dilakukan kampanye melalui pemasangan stiker, poster dan banner serta spanduk di seluruh kantor BPPT.

\section{e. Lomba Penghematan Air di Internal BPPT}

Untuk mendorong dan memotivasi budaya hemat energi dan air bagi pegawai BPPT serta memicu tumbuhnya inovasi teknologi di bidang konservasi energi, air dan lingkungan, sejak tahun 2015 dilaksanakan lomba Penataan Lingkungan Kerja dan Penghematan Energi dan Air di lingkungan BPPT yang pelaksanaannya bertepatan dengan acara ulang tahun BPPT. Kegiatan ini merupakan ajang penilaian tentang implementasi penghematan energi dan air baik dari segi organisasi, budaya pegawai dan sarana prasarana di lingkungan kerja pegawai BPPT serta penataan ruangan kerja pegawai dan lingkungan sekitarnya.

\section{f. Keikutsertaan Pada Lomba antar Instansi}

Untuk mengukur keberhasilan pelaksanaan Penghematan Energi dan air, hasil-hasil yang dicapai telah diikutsertakan pada acara Penghargaan Efisensi Energi Nasional (PEEN) yang diselenggarakan oleh Kementerian Energi dan Sumber Daya Mineral. Salah satu maksud dan tujuan dilaksanakannya acara ini adalah unuk memberikan apresiasi kepada Pemerintah Pusat dan Daerah yang telah berhasil menerapkan program-program penghematan energi dan air di Instansinya masing-masing ${ }^{(10)}$

\section{g. Inovasi Teknologi}

Salah satu komitmen untuk mendukung gerakan penghematan air adalah melaksanakan inovasi teknologi. Berbagai inovasi teknologi telah dihasilkan, antara lain:

(1) Kombinasi teknologi instalasi pengolahan air limbah (IPAL) perkantoran sistem biofilter dan teknologi daur ulang air limbah (Gambar 1) yang dapat menghemat pemakaian energi sekitar $25 \%$.

(2) Teknologi pemanenan air hujan, sumur resapan dan unit pengolahan air hujan menjadi air minum (Gambar 2). 


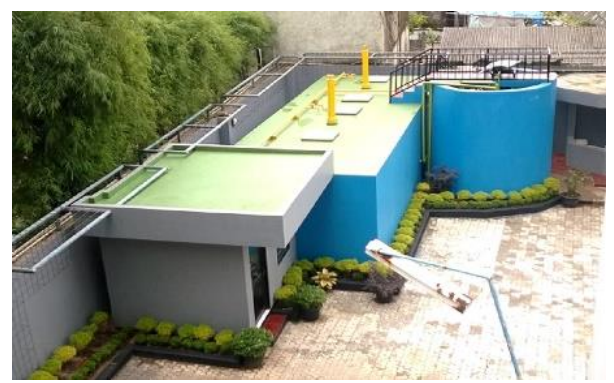

Gambar 1.Instalasi Pengolahan Air Limbah BPPT

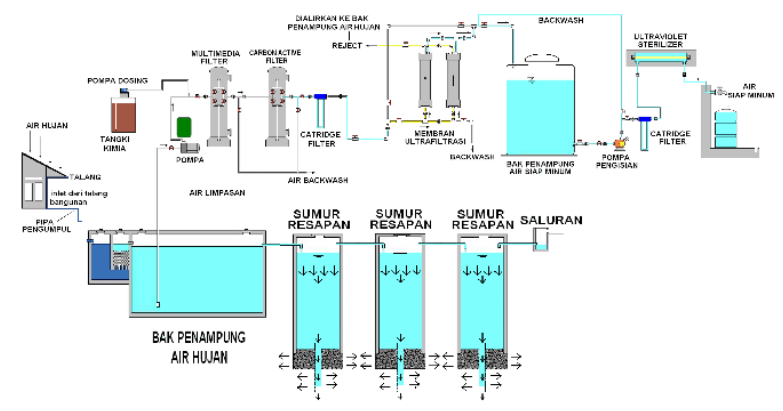

Gambar 2. Diagram Pemanenan Air Hujan, Sumur Resapan dan Unit Pengolah Air Minum

(3) Teknologi pengolahan air bersih dengan sistem ultrafiltrasi kapasitas 4-10 liter/menit dengan tenaga sepeda dan

(4) Teknologi pengolahan air minum dengan sistem ultrafiltrasi kapasitas 1.500 liter/jam dengan tenaga surya (solar cell).

\section{h. Pelaksanaan Rekomendasi Hasil Audit}

Dalam rangka melaksanakan rekomendasi hasil audit, telah dilakukan beberapa perbaikan dan upaya-upaya lainnya untuk penghematan air, antara lain:

\section{(1) Perbaikan dan Pemasangan Meter Air}

Meter air sangat penting untuk memantau secara terus menerus jumlah pemakaian air. Selain itu juga berfungsi untuk mengontrol dan mengendalikan pemakaian air setiap bulannya ${ }^{(12)}$. BPPT telah mengganti dan melakukan kalibrasi terhadap beberapa meter air yang tidak berfungsi. Selain itu juga dilakukan pemasangan meter air di titik yang berpotensi besar dalam pemakaian air seperti untuk pemakaian air di kantin dan dapur.

\section{(2) Pemakaian Keran Hemat Air}

Pemakaian keran hemat air bertujuan untuk memberikan kinerja tinggi sekaligus mengurangi jumlah air yang dibutuhkan.
Ada beberapa tipe utama keran yang telah diterapkan antara lain :

a. Keran aerator yang berfungsi untuk menggabungkan udara dengan air guna mengurangi percikan air dari keran ${ }^{(11)}$

b. Keran tekan (push taps) yang dapat menutup sendiri setelah dinyalakan/ ditekan (push) dalam waktu tertentu sehingga menghilangkan kemungkinan air dibiarkan mengalir. Pemakaian keran ini dapat menghemat air sampai 50\% dibandingkan dengan keran konvensional(12).

c. Keran sensor yang akan terbuka saat tangan mendekati keran dan otomatis akan berhenti mengalir jika tangan menjauh. Pemakaian keran sensor ini dapat menghemat air lebih dari $70 \%$ dibandingkan dengan pemakaian keran manual ${ }^{(13)}$.

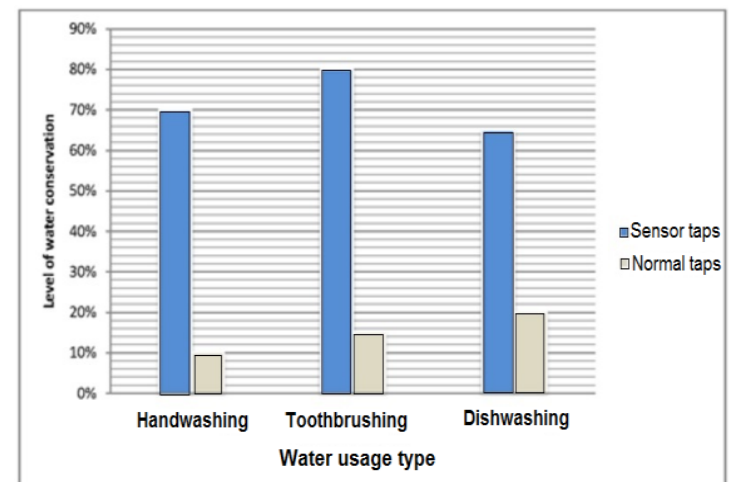

Gambar 5. Grafik Perbandingan Pemakaian Keran Sensor dan Keran Normal (13)

Penggunaan aerator mampu membatasi aliran dari keran. Bahkan 70 persen rumah tangga yang memasang aerator ini mampu mengurangi penggunaan air sebesar 13\% sampai $28 \%^{(14,15)}$. Penggunaan keran dengan aerator selain di toilet umumnya digunakan juga untuk keperluan pantry/dapur dan taman.

Pemakaian keran di dapur merupakan area yang membutuhkan konsumsi air dalam jumlah besar. Sekitar 35\% dari konsumsi air harian dihabiskan di dapur ${ }^{(16)}$. Perangkat aerator ini efektif untuk menghemat energi dan mengurangi konsumsi air keran karena menggabungkan udara dengan air yang mengalir dari ujung keran.

\section{(3) Pemakaian Dual Flush Toilet}

Toilet duduk yang menggunakan sistem "flush" menjadikan penyiraman otomatis 
dengan satu kali gerakan menjadi lebih efisien. Terdapat dua pilihan sistem flush yaitu single flush dan dual flush. Tipe single flush merupakan model klasik sedangkan tipe dual flush menggunakan perbandingan 3:6 liter di mana tombol kecil mengeluarkan 3 liter air dan tombol besar mengeluarkan 6 liter air (Gambar 16). Untuk lebih menghemat air beberapa produsen toilet membuat sistem perbandingan 3:4,5 liter dan 2,3: 4,8 liter $^{(17)}$.

Gedung I dan II BPPT Thamrin sebagian kecil sekitar $( \pm 10 \%)$ sudah menggunakan toilet duduk sistem dual flush, selebihnya masih menggunakan keran tekan (flushometer-valve toilet). Flushometer ini adalah alat penyiram toilet yang mengandalkan tekanan air dalam pipa distribusi bukan dari tangki penampung. Volume siram dari toilet flushometer ini dapat diatur sehingga menjadi lebih hemat $20 \%$.

\section{(4) Pemakaian Shower untuk Mandi}

Menurut United State Environmental Protection Agency's (EPA's) Water Sense Program standar shower yang digunakan harus mempunyai spesifikasi nilai maksimum flow rate sebesar 7,6 liter per menit. Menurut penelitian Aquacraft tahun 2005 rata-rata waktu mandi dengan menggunakan shower adalah 7,93 menit, sehingga pemakaian air untuk mandi dengan shower sebesar 60,27 liter ${ }^{(18)}$. Apabila dibandingkan dengan mandi menggunakan gayung dan bak mandi/ember akan membutuhkan 75 liter sampai 100 liter $^{(19)}$, maka mandi dengan menggunakan shower akan menghemat sampai 39\% air bersih.

BPPT telah menggunakan shower sebagai perangkat untuk mandi pegawai di kantor. Selain hemat air dan efisien juga menghemat tempat/space.

\section{(5) Pemakaian Sprinkler untuk Siram Taman}

Salah satu cara untuk menghemat air dalam aktivitas siram taman dan cuci kendaraan adalah dengan menggunakan teknik siraman air. Peraturan Menteri Pekerjaan Umum \& Perumahan Rakyat tentang Sumber Daya Air menjelaskan bahwa penerapan teknologi hemat air dalam menggunakan peralatan penyiraman tanaman dapat berupa irigasi curah (sprinkler) ${ }^{(20)}$. Sistem irigasi curah adalah metode pemberian air yang dilakukan dengan menyemprotkan air ke udara kemudian jatuh ke permukaan tanah seperti air hujan ${ }^{(21)}$.

BPPT telah memasang beberapa springkler dengan tipe impulse dengan cara kerjanya sangat baik, karena dapat disetting sudut putar yang diinginkan dan juga kebutuhan airnya dapat diatur karena terdapat pusat pengaturan air untuk penyiraman taman.

\section{(6) Daur Ulang Air Limbah}

Pemakaian air tanah yang akan semakin besar di masa mendatang, maka perlu dipikirkan bersama pemecahan yang terpadu untuk menangani masalah kebutuhan air bagi penduduk DKI Jakarta. Salah satu alternatif yang banyak mendapat perhatian di banyak negara di dunia adalah menggunakan daur ulang air limbah khususnya air limbah perkotaan (municipal waste) sebagai salah satu sumber air baku untuk penyediaan air (22)

Proses ini sangat tepat diaplikasikan terutama pada unit-unit usaha yang membutuhkan air bersih dalam jumlah yang besar. Beberapa keuntungan yang dapat diperoleh dari hasil daur ulang air limbah sebagai berikut:

a. Mengurangi ketergantungan pada air PAM dan air tanah,

b. Mengurangi pemakaian air PAM dan air tanah, sekaligus menghemat biaya untuk pengadaan air bersih,

c. Mengurangi produksi air limbah yang dibuang ke badan penerima air,

d. Menghemat pemakaian sumber daya alam dan ikut melestarikan lingkungan,

e. Proses daur ulang air semakin sederhana dan murah karena kemajuan teknologi.

BPPT mengembangkan teknologi daur ulang air limbah (Gambar 7 dan 8) dengan kapasitas $5 \mathrm{~m}^{3} / \mathrm{jam}$ untuk meningkatkan kualitas air limbah menjadi air bersih sesuai Baku Mutu yang disyaratkan sebagai air bersih menurut PerMenkes Republik Indonesia No. 16/MENKES/PER/IX/1990(23). Sistem daur ulang tersebut terdiri dari Sistem Pre-treatment dan Advance Treatment. Pre-treatment ditujukan untuk mengurangi kekeruhan, kelebihan $\mathrm{Fe}-\mathrm{Mn}$, senyawa organik (secara terbatas) yang menyebabkan bau dan warna, melalui proses-proses pencampuran, oksidasi, filtrasi dan absorpsi. Advance Treatment mengakomodasi proses-proses mikro-ultra filtrasi. 


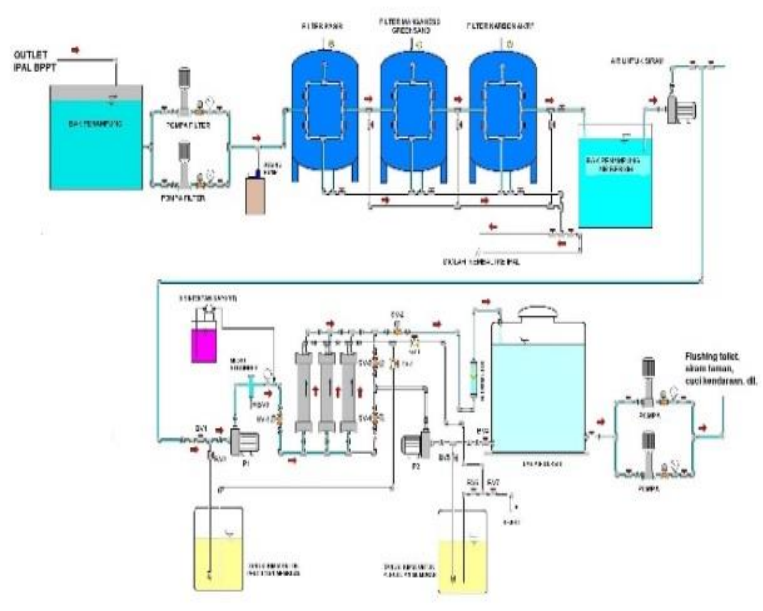

Gambar 7. Diagram Unit Daur Ulang Air Limbah

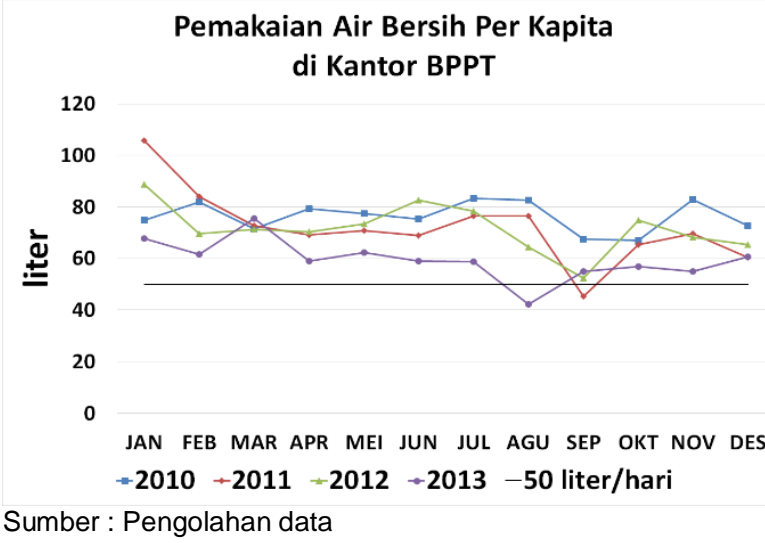

Gambar 8. Jumlah Pemakaian Air Bersih Ratarata perkapita (liter/orang.hari) Tahun 2009 s.d. 2013

\section{(7) Pemakaian Air Hujan}

Upaya pemanfaatan air hujan sudah banyak dilakukan di banyak negara. Teknologi yang digunakan juga merupakan teknologi sederhana dan dapat dengan mudah diimplementasikan dan dilakukan di masyarakat. Menurut peraturan Menteri Negara Lingkungan Hidup No. 12 tahun 2009 Tentang Pemanfaatan Air Hujan Pasal 1 Ayat 1 menyebutkan bahwa pemanfaatan air hujan adalah serangkaian kegiatan mengumpulkan, menggunakan, dan/atau meresapkan air hujan ke dalam tanah. Sedangkan pada Ayat 3 disebutkan, kolam pengumpul air hujan adalah kolam atau wadah yang dipergunakan untuk menampung air hujan yang jatuh di atap bangunan (rumah, gedung perkantoran atau industri) yang disalurkan melalui talang ${ }^{(24)}$.

\section{(8) Sistem Sumur Resapan Air}

Air buangan AC dari gedung II BPPT cukup tinggi sekitar $1,8 \mathrm{~m}^{3} /$ hari yang terbuang percuma, maka dimanfaatkan sebagai masukan sumur resapan air tanah dalam. Sumur resapan merupakan salah satu cara konservasi air tanah.

Adapun manfaat yang dapat diambil dari pembuatan sumur resapan adalah:

a. Sumur resapan mempunyai manfaat untuk menambah jumlah air yang masuk ke dalam tanah.

b. Sumur resapan dapat menambah jumlah air yang masuk kedalam tanah, sehingga dapat menjaga kesetimbangan hidrologi air tanah sehingga dapat mencegah intrusi air laut.

c.Mereduksi dimensi jaringan drainase.

d. Menurunkan konsentrasi pencemaran air tanah.

e. Mempertahankan tinggi muka air tanah.

f. Sumur resapan mempunyai manfaat untuk mengurangi limpasan permukaan sehingga dapat mencegah banjir.

g. Mencegah terjadinya penurunan tanah.

\subsection{Effisiensi Pemakaian Air Sebelum dan Sesudah Dilakukan Upaya Penghematan Air}

\section{a. Hasil Audit}

Hasil audit yang telah dilakukan oleh Pusat Teknologi Lingkungan sebagai unit yang berkompeten, antara lain adalah ${ }^{(25)}$ :

(1) Sumber air bersih yang digunakan di Kantor BPPT $100 \%$ berasal dari PAM Palyja.

(2) Sumber air bersih tambahan diperoleh dari hasil pengolahan unit daur ulang, digunakan untuk siram tanaman, cuci-cuci dan flushing toilet di Gedung Parkir; Pemakaian air bersih per kapita/liter/hari tahun 2010 sebesar 76,36 liter/hari sampai tahun 2013 turun menjadi 59,82 liter/hari (Gambar 8);

(3) Rata-rata penggunaan air bersih yang digunakan di lingkungan Kantor BPPT dari tahun 2009 hingga tahun 2013 terjadi penurunan yang cukup besar yaitu sekitar $32,80 \%$ (Gambar 9);

(4) Terdapat meter air yang rusak, sehingga perlu secepatnya diperbaiki atau diganti. 


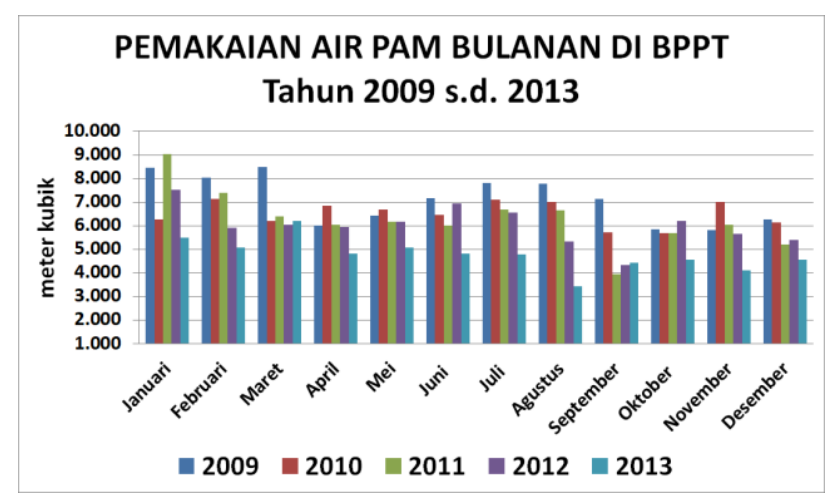

Sumber : Pengolahan data

Gambar 9. Jumlah Pemakaian Air Bersih PAM ( $\mathrm{m}^{3} /$ bulan) Tahun 2009 s.d. 2013

\section{b. Pemakaian Kran}

Saat ini pemakaian keran hemat air telah digunakan/dipasang dengan tujuan untuk penghematan pengunaan air di hampir setiap washtafel toilet di Kantor BPPT. Pada gambar 10 terlihat bahwa di gedung I BPPT pemakaian keran tekan hemat air sudah terpasang $(65,22 \%)$ sisanya masih menggunakan keran manual. Sedangkan di Gedung II sebagian besar washtafel toilet sudah dipasang keran sensor $(54,17 \%)$ dan sebagian sudah terpasang keran tekan $(37,50 \%)$, sisanya masih menggunakan keran manual $(4,17 \%)$.

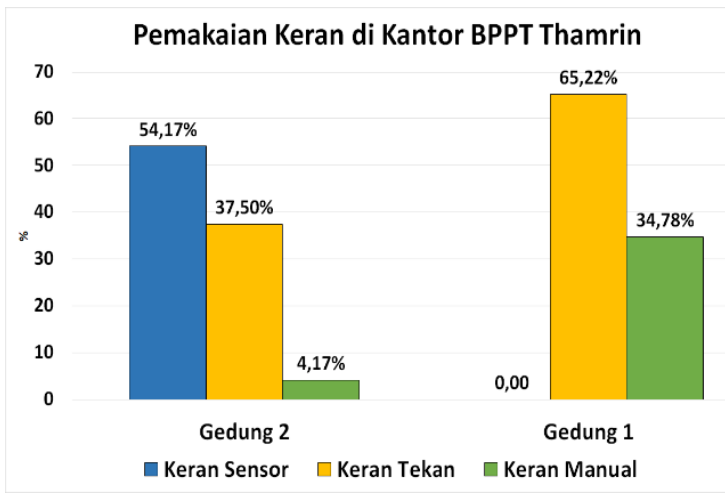

Sumber : Pengolahan data

Gambar 10. Grafik Pemakaian Jenis Keran di Kantor BPPT

\section{c. Penampungan Air Hujan}

BPPT telah membuat penampungan air hujan (PAH) dengan volume $5 \mathrm{~m}^{3}$, dilengkapi dengan sistem penyaringan yang berupa saringan pasir dan kerikil (Gambar 11 dan 12). Sistem penyaringan ini untuk menyaring daundaun, debu atau pasir yang jatuh di atap gedung, sehingga tidak masuk kedalam $\mathrm{PAH}$. Kemudian air dari PAH di pompa ke multimedia filter kemudian dialirkan ke bak penampung air bersih. Air bersih dipompa ke bak penampung bersama air hasil daur ulang untuk keperluan siram taman, flushing toilet dan lainnya.

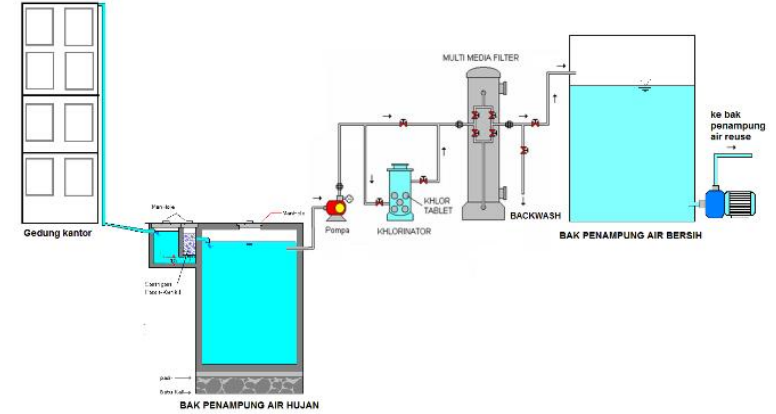

Gambar 11. Diagram Unit Pengolah Air Hujan dapat digunakan untuk air minum dan sumur resapannya.

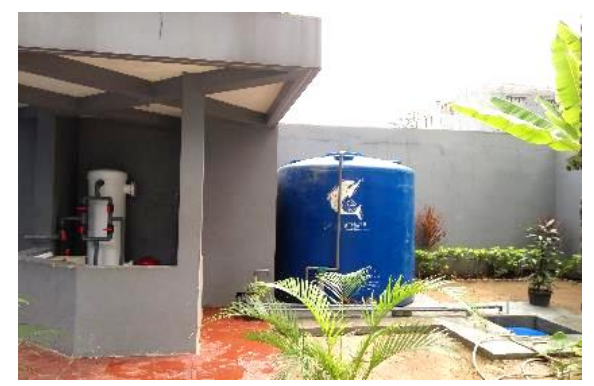

Gambar 12. Unit Pemanenan Air Hujan

Dengan menggunakan rumus $Q=A \times M \times F$, (26) dapat dihitung potensi air hujan yang dapat ditampung, dimana:

$\mathrm{Q}=$ kuantitas air hujan $\left(\mathrm{m}^{3}\right)$

$A=$ luas area penangkapan air hujan $\left(\mathrm{m}^{2}\right)$

$M=$ curah hujan rata-rata $(\mathrm{mm} /$ hari $)$

$\mathrm{F}=$ koefisien pengaliran atau run-off

Luas area atap $(40 \times 20) \mathrm{m}^{2}$, rata-rata curah hujan di Jakarta tahun 2014 adalah 7,37 $\mathrm{mm} /$ hari, maka diperoleh volume kuantitas air hujan sebesar: $Q=8.000 \times 7,37 \times 0,9=53,1 \mathrm{~m}^{3}$.

\section{d. Sumur Resapan}

Di area gedung BPPT telah dibuat sumur resapan dengan kedalaman 193 meter dengan menempatkan screen pada akuifer dengan kedalaman 139-162 meter dan 167-184 meter. Dari perhitungan uji coba kapasitas infiltrasi untuk sumur dalam berkisar antara 1,23 sampai $2,1 \mathrm{~m}^{3} / \mathrm{jam}^{(27)}$ (Gambar 13).

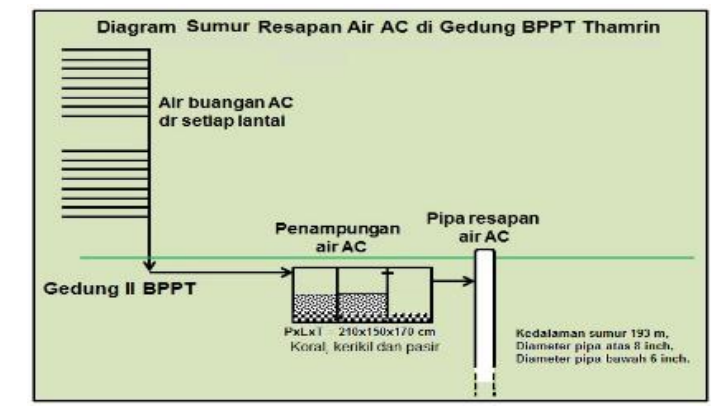

Gambar 13. Diagram Sumur Resapan Air buangan Air Conditioning (AC) 


\section{e. Daur Ulang}

Air bersih hasil daur ulang air limbah digunakan sebagai: siram tanaman, cuci kendaraan, cooling tower, flushing toilet dan sebagainya (Gambar 14). Rata-rata pemakaian air PAM di BPPT tahun 2010 adalah 208,74 $\mathrm{m}^{3} /$ hari $^{(28)}$. Apabila unit daur ulang dioperasikan selama 12 jam/hari, maka air bersih yang dihasilkan sebesar $60 \mathrm{~m}^{3} /$ hari. Berdasarkan perhitungan di atas maka unit daur ulang dapat menghemat pemakaian air bersih PAM sebesar $28,74 \%$.

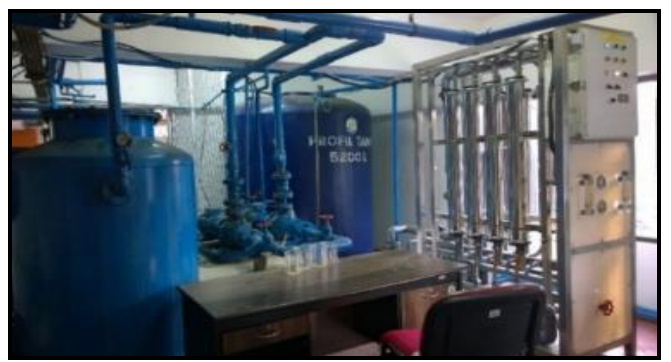

Gambar 14. Unit Daur Ulang Air Limbah

\section{f. Penurunan Pemakaian Air}

\section{Setelah dilakukan}

upaya-upaya penghematan pemakaian air, maka untuk mengetahui seberapa besar penghematan tersebut akan dibandingkan pemakaian air bulanan tahun 2010 dengan tahun 2015. Gambar 15 memperlihatkan bahwa hasil perbandingan tersebut menunjukkan terjadi penurunan pemakaian air yang cukup signifikan rata-rata sebesar $38,13 \%$.

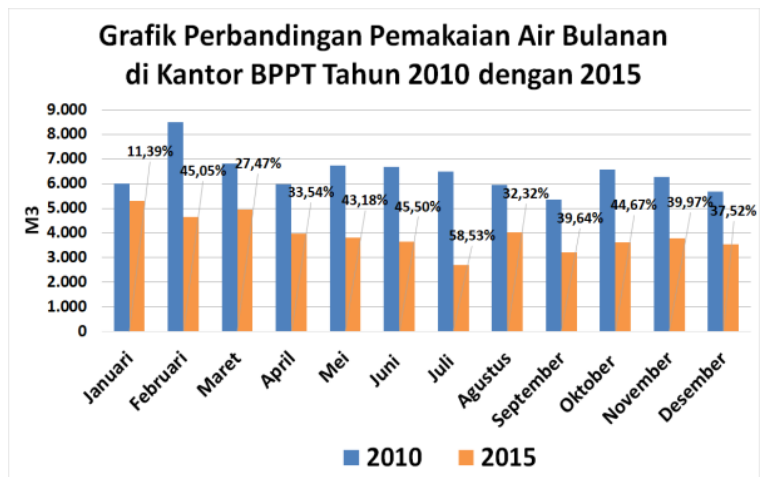

Sumber : Pengolahan data

Gambar 15. Persentase Perbandingan

Pemakaian Air PAM Bulanan Tahun 2010 dengan 2015

\section{g. Hasil Lomba Antar Instansi}

Pada tahun 2016 BPPT untuk pertama kali mengikuti lomba pada kategori Penghematan Energi dan Air, Sub Kategori Pemerintah Pusat dan berhasil keluar sebagai pemenang pertama (29).

\section{KESIMPULAN}

Sebagai hasil dari gerakan penghematan air, BPPT telah mampu melaksanakan efisiensi sebesar $38,13 \%$ dari tahun 2010 s.d. 2015, yang diperoleh dari :

- pembangun unit daur ulang air limbah yang dapat menghemat pemakaian air sebesar $28,74 \%$,

- pemanenan air hujan yang dapat menghemat $2,4 \%$ dan apabila diperbesar bak penampungnya dapat ditingkatkan menjadi sekitar $20 \%$,

- pembuatan sumur resapan dapat menjaga kesetimbangan hidrologi air tanah sehingga dapat mencegah intrusi air laut.

- Serta penghematan lain yang diperoleh dari kegiatan penggantian kran-kran dan peralatan sanitary lainnya yang hemat air

Hasil penghematan air bersama dengan penghematan energi BPPT ini telah memperoleh pengakuan sebagai pemenang pertama pada lomba PEEN katagori Penghematan Energi dan Air, Sub Kategori Pemerintah Pusat, yang diselenggarakan oleh Kementerian Energi dan Sumberdaya Mineral pada tahun 2016.

Adapun faktor yang paling utama dari upayaupaya penghematan air di perkantoran adalah komitmen dari Top Manajemen untuk mendukung secara penuh pada gerakan penghematan air.

\section{PERSANTUNAN}

Ucapan terima kasih disampaikan kepada Kepala Biro Umum BPPT beserta jajarannya yang berperan aktif dalam pelaksanaan kegiatan penghematan energi dan air di BPPT. Juga kepada Direktur Pusat Teknologi Lingkungan, TPSA-BPPT dan semua stafnya yang telah mendukung penuh kegiatan penghematan energi dan air di lingkungannya serta BPPT secara umum.

\section{DAFTAR PUSTAKA}

1. Yudo. S., Taty H. (2006). Kebutuhan Air Bersih Masyarakat di daerah Perdesaan Nelayan (Di Wilayah Pesisir Kabupaten Pasir, Kaltim). Jurnal Air Indonesia, Vol. 2, No. 2, BPPT.

2. Anonim. (2008). Peraturan Pemerintah Nomor 42 Tahun 2008 Tentang Pengelolaan Sumber Daya Air.

3. Anonim. (2011). Instruksi Presiden Republik Indonesia Nomor 13 Tahun 2011 Tentang Penghematan Energi dan Air.

4. Anonim. (2012). Peraturan Menteri Energi dan Sumber Daya Mineral Republik Indonesia Nomor 15 Tahun 2012 Tentang Penghematan Penggunaan Air Tanah. 
5. Yudo S. (2015). Pemakaian dan Penghematan Air Bersih di Kantor BPPT. Prosiding Seminar Nasional : "Inovasi Teknologi Lingkungan dalam Aksi Gerakan Nasional Indonesia Bersih". BPPT, Hal. 302.

6. Anonim. (2017). Kamus Besar Bahasa Indonesia (KBBI). Available from : (https://kbbi.web.id/komitmen)

7. Anonim. (2016). Awareness and Implementing An Energy Management System. Bahan Training hal. 39. Catur Daya Solusi, PT., Jakarta.

8. Arens, Alvin. A., Elder, dan Beasley. (2008). Auditing dan Jasa Assurance Pendekatan Terintegrasi Jilid 1. Edisi kedua belas. Jakarta: Erlangga.

9. Anonim. (2013). Laporan Audit Penggunaan Air Bersih di Kantor BPPT. Pusat Teknologi Lingkungan, BPPT.

10. Anonim. (2016). Penghargaan Efisiensi Energi Nasional ESDM 2016: BPPT Raih Peringkat Pertama Hemat Energi dan Air. Biro Hukum, Kerjasama dan Hubungan Masyarakat, BPPT. Available from: (http://www.bppt.go.id/layanan-informasipublik/2685-penghargaan-efisiensi-energinasional-esdm-2016-bppt-raih-peringkatpertama-hemat-energi-dan-air)

11. Anonim. (2014). Guide to Faucet Aerators, Using an aerator helps save water in one easy step. Available from :

https://www.plumbingsupply.com/aboutfaucet-aerators.html

12. Anonim. (2014). Saving Water, Saving Money: Taps and Showers. Resource Efficient Scotland. Available from:

(http://www.visitscotland.org/pdf/Sustainabilit y\%20Leaflet\%20-\%20Water\%20-

$\% 20$ Taps\%20and\%20Showers.pdf)

13. Anonim. (2013). Automatic Taps Facts And Charts. Autotaps (UK) Limited, London.

Available from:

(http://www.autotaps.com/sensor-taps-factsand-charts.html)

14. Rizqi dkk. (2010). Pengaruh Aerator Keran Terhadap Volume Air yang Digunakan untuk Mencuci Tangan. Karya Tulis IImiah, SMP Negeri 41 Jakarta. Pembimbing: Heksi Dewi Maulina, SPd.

15. Anonim. (2017). Menghemat Air dengan Aerator Keran. Available from : (http://www.sarana-bangunan.com/ menghemat-air-dengan-aerotor-keran/)

16. Lu, Tingyi. (2007). Research of domestic water consumption: a field study in Harbin, China. A research project report submitted in partial fulfilment of the requirements for the award of the degree of Master of Science of Loughborough University.
17. Sofyan A. (2013). Kloset Flush yang Makin Efisien. Available from :

(http://properti.kompas.com/read/2013/09/02 / 1210439/Kloset.Flush.yang.Makin.Efisien)

18. Anonim, (2010). WaterSense Specification for Showerheads Supporting Statement. United State Environmental Protection Agency's (EPA's) WaterSense.

19. Khamdevi, Moh. (2012). Aplikasi Penggunaan Air Dalam Figh Pada Bangunan Hunian: Reduce, Reuse dan Recycle?. Program Studi Arsitektur Universitas Pembangunan Jaya.

20. Anonim. (2015). Peraturan Menteri PUPR Nomor 9/PRT/M/2015 tentang Penggunaan Sumber Daya Air.

21. Romadon, K. (2014). Rancang Bangun Sistem Irigasi Curah (Sprinkler) Jenis Challanger. Skripsi, Fakultas Pertanian Universitas Lampung.

22. Said, Nusa Idaman. (2006). Daur Ulang Air Limbah Ditinjau dari Aspek Teknologi, Lingkungan dan Ekonomi, Jurnal Air Indonesia, Vol. 2, 2006.

23. Anonim. (1990). Peraturan Menteri Kesehatan RI No. 416 Tahun 1990 Tentang Syarat-syarat dan Pengawasan Kualitas Air.

24. Anonim. (2010). Laporan Pemakaian Air Bersih Kantor BPPT, Bagian Perlengkapan, Biro Umum, BPPT.

25. Anonim. (2013). Laporan Audit Penggunaan Air Bersih di Kantor BPPT. Pusat Teknologi Lingkungan, BPPT.

26. Idaman, N., Widayat, W. (2014). Pengisian Air Tanah Buatan, Pemanenan Air Hujan Dan Teknologi Pengolahan Air Hujan "Studi Kasus Kota Depok". BPPT.

27. Sudinda, W.T. et al. (2009). Kajian Dan Penerapan Teknologi Artificial Recharge Air Tanah Dalam untuk Mengatasi Banjir dan Kekeringan. Prosiding Workshop Teknologi Imbuhan Buatan untuk Mengatasi Banjir dan Kekeringan. Deputi Bidang Pendayagunaan dan Pemasyarakatan IPTEk. KemenRistek. Jakarta.

28. Anonim. (2010). Laporan Pemakaian Air Bersih Kantor BPPT, Bagian Perlengkapan, Biro Umum, BPPT.

29. Anonim. (2016). Penghargaan Efisiensi Energi Nasional ESDM 2016: BPPT Raih Peringkat Pertama Hemat Energi dan Air. Biro Hukum, Kerjasama dan Hubungan Masyarakat, BPPT. Available from:

(http://www.bppt.go.id/layanan-informasipublik/2685-penghargaan-efisiensi-energinasional-esdm-2016-bppt-raih-peringkatpertama-hemat-energi-dan-air) 
